\title{
Rancière and the Metapolitical Framing of Architecture: \\ Reconstructing Brodsky and Utkin's Voyage
}

\author{
Michael J. Ostwald
}

\section{Architecture in the post-political world}

For Kenneth Frampton (1992: 8), the construction of architectural history generally relies on a consideration of architectural polemics. However, of even greater importance are the "socio-economic or ideological circumstances" shaping the production of architecture. Most histories of architecture in the service of politics are founded on the assumptions that political systems are innately ideological, and that architecture produced under these regimes reflects the values and beliefs of the political system (Millon and Nochlin, 1978; Dovey, 1990; Schumacher, 1993). While the proposition of a causal reflection of ideology in design has been questioned, the premise that political systems necessarily possess an identifiable and stable ideology remains largely unchallenged (Findley, 2005).

However, in the last few decades conventional political belief systems (like socialism or fascism) are being supplanted by governing structures which do not strive to achieve some social ideal or uphold a moral principle. Instead, their goals are expressed through economic or managerial concepts including growth, transparency, productivity and security. This is not to suggest that contemporary politics lacks ideological values; rather, these values are hidden, repressed or subservient, and are rarely apparent in the artefacts they produce. Similarly, these systems are called post-political, not because they are no longer concerned with steering a nation state, but because they have arisen in the aftermath of failure in a dominant ideological system. Thus, the post-political condition encompasses both the apparent loss of ideology and the lacunae that results from regime failure.

Jacques Rancière and Alain Badiou argue that in the post-political world any association between a system of governance and the physical artefacts produced under its guise (like art or architecture) is more complex, and contingent, than it is under more overtly ideological and stable regimes. For this reason, the interpretation of architecture requires new concepts and techniques. A case in point is Russian architecture since the demise of communism in the 1980s when, significantly, a regime failure occurred and an ideologically based system was replaced with a managerial one.

Conventional interpretations of early 20th century architecture in Communist Russia draw clear programmatic and formal parallels between the ideology of the state and the designs produced by its architects; between aesthetics and power 
I. Brodsky and Utkin's collaborative works are recorded in one major monograph published in 1990 ; it was expanded and updated without change in theoretical or historical framing in 2003. Over 20 books and catalogues, and 70 newspaper articles and reviews in professional journals feature their work, mostly predating 1994. The majority of readily available sources are either purely descriptive or they are uncritical of the dominant ideological positioning Brodsky and Utkin's collaborative designs and installations have been represented in almost 40 joint and group shows in Europe, North America and Australasia (including Sydney in 1991 and Wellington in 1992)

2. Rancière divides the common sense notion of the political into 'police' (la politique/police) and 'politics' (la politique/politique), where 'police' is the current partition of the sensible and 'politics' is a means for disrupting it. Disagreement is the essence of politics (see Rancière 2000: II).

3. For Rancière les arts plastiques include jewellery, sculpture and architecture. Rancière(2007b) uses the phrase "aesthetic object" to denote a wide range of labour products that include literature, design, the arts and performance. While Rancière (2004c) explicitly acknowledges architecture as an aesthetic object, he appears to consider the text, and its incarnations in poetry or fiction, as the ideal analytical subjects.
(Khan-Magomedov, 1987; Papadakis, 1991). This direct projection of ideology into space, form and materiality is supported by Constructivist manifestos (Kopp, 1970; 1985). However, the same method of historical interpretation permits a different, equally ideologically inspired reading of the neoclassical architecture authorised by the soviet state in the 1960s (Brumfield, 1991; Bown and Taylor, 1993). Moreover, these techniques are problematic when applied to the post-communist architecture that arose during the dissolution of the Soviet Union.

For instance, Alexander Brodsky and Illya Utkin produced their most famous unbuilt designs in the years immediately following the liberalisation of the Soviet economy, during the era Badiou describes as the "death of communism" (2004: 126). A canonical interpretation of the place of Brodsky and Utkin in world architecture - in Sir Banister Fletcher's, a history of architecture - describes Brodsky and Utkin's formative years as a precursor to "developing the confidence to" use architecture to "attack the defeatism and complacency of the professional establishment" (1996: 1444) in the Soviet Union. Variations of this interpretation - architecture as reaction to, and criticism of, the impact of a stifling political ideology on architecture - are repeated in the only monograph on Brodsky and Utkin, in the major catalogues of their work, and in newspaper articles. ${ }^{1}$ Because their architecture appears to reject the values of communism, a conventional historical reading opposes their work to the dominant ideological position of the state. However, if Brodsky and Utkin's work is viewed as the product of either a regime change, or the rise of an apolitical system, then it cannot simply be defined in opposition to communism.

Using the theories and methods of Rancière, this paper develops an account of the political framing of Brodsky and Utkin's architecture. ${ }^{2}$ Importantly, its purpose is not to formulate a counter history, but rather to offer an alternative understanding of the fabrication of history. The limited number of examples contained in the present paper does not permit a complete reinterpretation of Brodsky and Utkin's architecture. More importantly, Rancière's methods do not support the production of any definitive historical evaluation of any cultural artefact, in any political context. In his view, history is not fixed or immutable, but simply a story which presents itself as telling the truth (1994). Thus, studying the construction of history (the combination of unseen political forces, structures and orders) is more rewarding than reading history. Rancière's methods provide a range of mechanisms that are significant for the framing (interpretation or critical positioning) of architecture in a world where political systems are neither stable nor founded on traditional ideologies.

\section{Rancière's Metapolitics}

Jacques Rancière has written on the importance of intellectual emancipation (1991), social equity (2004a), the power of language $(1994 ; 2004 c)$, the problems of democracy (2007a) and, important to the present context, the relationship between les arts plastiques and politics (2004b). ${ }^{3}$ While originally a supporter of socialism, Rancière rejected all mainstream political systems in the aftermath of the civil unrest in France, May 1968. He turned his attention instead to understanding the rules and mechanisms which sustain political structures. Badiou (2005) characterises Rancière's theoretical method as Metapolitical: a 
philosophy of politics that does not come from a distinct ideological tradition, but which considers operations both within and across multiple governing structures. The challenge of Rancière's method is his awareness that his own arguments are necessarily part of the political structures he is analysing. This awareness leads Rancière to write in a manner which Hayden White characterises as "nonnarrative and nondiscursive, aphoristic, almost oracular" (1994: xviii). Badiou (2005) traces the origins of this use of language to Rancière's desire to speak only from within his Metapolitical domain - to avoid the artificial distancing that Metapolitical thought usually entails. In order to understand Rancière's recent theory of the relationship between aesthetics and politics, it is important to consider his earlier explanation of the rise of apolitical systems.

In 1988, Rancière presented the first of a series of papers which argued that particular spatial and philosophical figures are brought into focus by the "end of politics itself" (1995: 3). Rancière's, On the shores of politics, commences with the proposition that the relationship between philosophy and politics has historically been articulated through spatial metaphors. Accordingly, the failure of major political systems in the 1980s (in Russia, South America and Europe) corresponds to a shift away from conventional topographic distinctions (between left or right, socialist or fascist) towards a more contingent and operational model. The old boundaries that once divided political orthodoxies may no longer exist, but the topography of political boundaries is still in use:

To speak of the boundaries of the political realm would seem to evoke no precise or current reality. Yet legend invariably has the political begin at one boundary ... and end up at another ... riverbanks of foundation, island shores of refoundation ... There must surely be something of the essence in this landscape for politics to be so stubbornly represented within it. And we know that philosophy has played a signal part in this stubbornness. Its claims in respect of politics can be readily summed up as an imperative: to shield politics from the perils that are immanent to it, it has to be hauled on to dry land, set down on terra firma. (1)

Rancière's politico-spatial topography is aquatic and estuarine; it recalls Plato's division between the power of the Athenian political state, which is invested in its shipping fleets, and the philosophical foundations of its governing structure, located in the terrestrial urban forum. For Rancière, the problem of approaching politics from a philosophical perspective is that it involves leaving the shore and "surrendering ... to the whims of tides and mariners" (1995: 2). However, where once political vessels set out to cross borders in search of "isles of utopia", in the last decades of the 20th century they are no longer so ideologically motivated, and are more concerned with "the art of steering the ship and embracing the waves, in the natural, peaceful movement of growth" (1995: 5-6). In Rancière's terms, this is the era of the "death of politics", the "end of political divisions, of social antagonisms and utopian projects" (1995: 3). In its place has arisen a time of growth, capitalism and trade. With the end of politics, the philosophers' role to guide or ground utopian voyagers is rendered obsolete. Instead, they must look within what remains of the political structure, to uncover and expose its component parts, its processes and outcomes. ${ }^{4}$ In order to do this, Rancière develops an alternative understanding of political systems in terms of the "distribution of the sensible".
4. Badiou is critical of Rancière's retreat from the consideration of ideological politics because it leads to "taking up political results by cutting them off from the processes that give rise to them. This practice ultimately relies upon what [Rancière] himself highlights as a philosophical imposture: forgetting the real condition of one's speech" (2005:I2I). 
5. Badiou defines his own Metapolitical theory as being reliant on the "the state of the situation"; a term he uses to describe "the correlation between the counting and non-counted" (2005: II6). Regarding the strong parallels between his own theory and Rancière's, Badiou argues that his own preceded Rancière's and is ultimately more useful for its underlying ontology; something Rancière has been criticized for lacking. Rancière, in a rare footnote, acknowledges some indebtedness to Badiou but counters that his "distribution of the sensible" has critical differences (1995: 37).
White argues that the key to understanding Rancière's "distribution of the sensible" lies in the proposal that:

participation in politics hinges on conceptions of membership in communities whose pedigrees are either confirmed or denied by an appeal to "history". But this "history" is a construction of those who already enjoy membership and indeed privileged positions in already formed communities (1994: ix).

For Rancière, every society is constructed upon a "system of self-evident facts of sense perception that simultaneously discloses the existence of something in common and the delimitations that define the respective parts and positions within it" (2004b: 12). Rancière refers to both a system of organisation (a delineation of elements), and the extent to which an individual has a voice in this system. Rancière's word "sensible" relates to what is seen or enabled; it refers to the actions or expressions a society finds acceptable. The relationship between art, architecture and politics is necessarily concerned with the distribution of the sensible (2007b), and defined by the "delimitation of ... the visible and the invisible, of speech and noise" (2004b: 13). The invisible, by its very nature, has little impact on the set of rules or values of a society, ${ }^{5}$ its "police order". Just as the distribution of the sensible encompasses a wide array of modes of operation (not just rights of membership or expression), the police order is more than the uniformed officers of the state: it includes everything from the media and social mores, to theological values and cultural practices. Indeed, the "essence of the police ... is not repression but rather a certain distribution of the sensible that precludes the emergence of politics" (2004b: 89).

One final and significant dimension of the distribution of the sensible concerns the nature of opposition or disagreement. Actions, events or representations which diverge from the police order are examples of "dissent". Actions, events or representations which seek to radically alter the distribution of the sensible are examples of "dissensus" with political intent. Simplistically, the former is the breaking of a law, while the latter is the advocacy of widespread lawbreaking. In part, the difference is between disagreeing with the distribution of the sensible and actively seeking to subvert or change it. However, the distinction between dissent and dissensus is more complex; it is also context sensitive. Thus, it relies on the extent to which a transgression of the distribution of the sensible is made apparent; as Rancière reminds the reader, politics necessarily "revolves around what is seen" (2004b: 13). The same transgressive event that occurs in private, but is later broadcast through the media, can potentially shift from dissent to dissensus as it becomes more visible. However, when interpreted in a different police order (a context with different social and cultural values) this same event may not be transgressive at all.

The key here is in the way the event is positioned or made visible, not in the event itself. Rancière rejects any assumption that there are correct, ideal or necessarily authoritative interpretations of events. Each successive framing must be viewed in its own terms. Nevertheless, the rules for understanding the distribution of the sensible remain constant across political topographies, even if the values embodied in the police order vary. The essence, as White observes, is not "what are" the facts or events, but "what can count" (1994: x)? Facts or events matter through 
their visibility and framing, their being counted. Rancière's methods allow relational framing to be dissected without recourse to political ideology, and his understanding of political systems, through the distribution of the sensible, provides a method for investigating the dominant interpretation of Brodsky and Utkin's architecture.

\section{Children of Stagnation}

In 1988, when Rancière was lamenting the loss of political will to seek utopian isles, Brodsky and Utkin were completing a project appropriately entitled $A$ Ship of Fools. This project, which has strong resonances with many of Rancière's concepts, depicts a "merry group of friends carous[ing] on the roof of an unsteady skyscraper in a sea of smoking chimneys" (Rappaport, 1994: 138). The "fools" are caricatures of Brodsky, Utkin and many of their fellow Paper Architects, "who performed a version of this merry ritual to help them survive the years of stagnation" (Boym, 1992: 38). In the single etching comprising this project, Brodsky and Utkin symbolise, in the form of the timber, ship-like skyscraper, their own architectural endeavours over the previous decade. Every beam and column, every shadow and surface is rendered with care. As the skyscraper sways beneath their feet, the architects bravely celebrate their achievements while feigning ignorance of the precarious nature of their existence. Like the Soviet state at that time, which was, to use Rancière's metaphor, sailing without direction but with a newfound commitment to the trim of the rigging and the luff of the sail, the Ship of Fools is rudderless but exquisitely detailed. While Rancière, the philosopher, laments the need to enter ideologically charged waters at a time when political mariners have lost sight of their destination, Brodsky and Utkin are depicted as oblivious to their course. Without the guiding charts of ideology, the celebrations of politicians and Paper Architects soon shift from being the traditional socialist "banquet of equals", to being a gluttonous wake for the lost navigator (Rancière, 1995: 65). As Badiou argues, "Rancière tends to identify politics in the realm of its absence, and from the effects of its absence" (2005: 122). In Brodsky and Utkin's project, the significance of politics is precisely that it is absent. The Ship of Fools is an architectural vessel for the post-political era; its politics are not clear, in the sense that it neither criticizes nor supports communism, although its Metapolitical commentary on the state of architecture adrift in society is. This project is one of many where the canonical interpretation of Brodsky and Utkin's architecture (as critical of the Soviet state or the architectural profession) is unconvincing. Therefore, how did the political framing of Brodsky and Utkin's architecture occur? The first stage in tracing this process involves positioning their work in relation to the traditional, ideologically understood, history of Russian architecture.

Alexander Rappaport traces the end of architectural freedom in the Soviet Union to the 1930s. Since then, "the architecture of the Soviet Union had been if not actually dead, then at least considered to be so ... and any exceptions were eliminated through the system of state and party control" (1994: 129). Mikhail Belov similarly asserts that, from the 1930s, there is "a blank which lasted for fifty years" in the architectural history books on Russia (1988: 6). Initially, this absence could be traced to Stalin's predilection for repetitive neoclassicism. However, in 1957, Nikita Khrushchev famously denounced Stalin's advocacy of neoclassical design, calling instead for the party to endorse a utilitarian, modern architecture. The result of Khrushchev's action was, as Alexey Tarkhanov records, that the

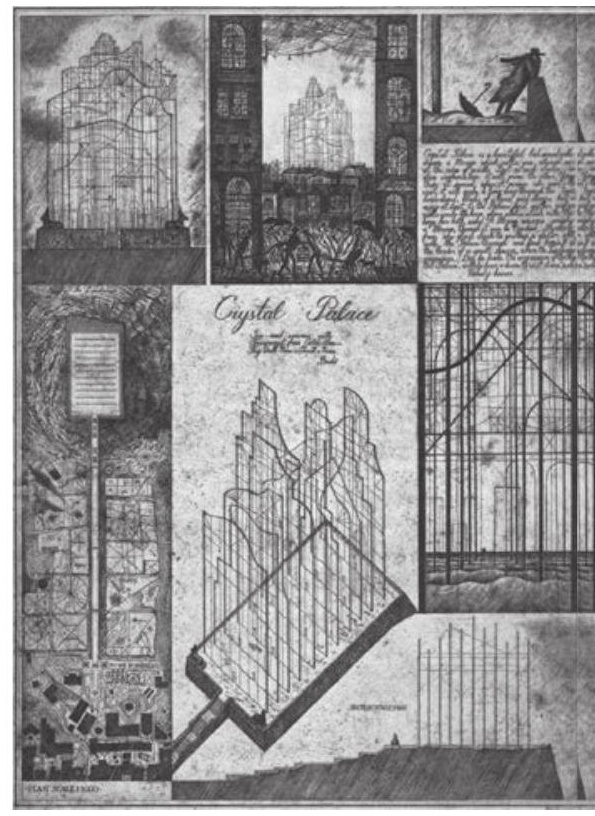

Brodsky \& Utkin, A Ship of Fools, 1988/90 (Plate produced / Plate printed) from Projects portfolio, 1981-90, 35 etchings, ed. of 30, $43 x$ 31 3/4 inches (F). Courtesy Ronald Feldman Fine Arts, New York. Photo by D. James Dee. [Originally drawn in 1988 and published in 1989] 
Brodsky \& Utkin, Crystal Palace, 1989/90 (Plate produced / Plate printed) from Projects portfolio, 1981-90, 35 etchings, ed. of 30, 43 $x 31$ 3/4 inches (F). Courtesy Ronald Feldman Fine Arts, New York Photo by D. James Dee. [Originally drawn and published in 1982]

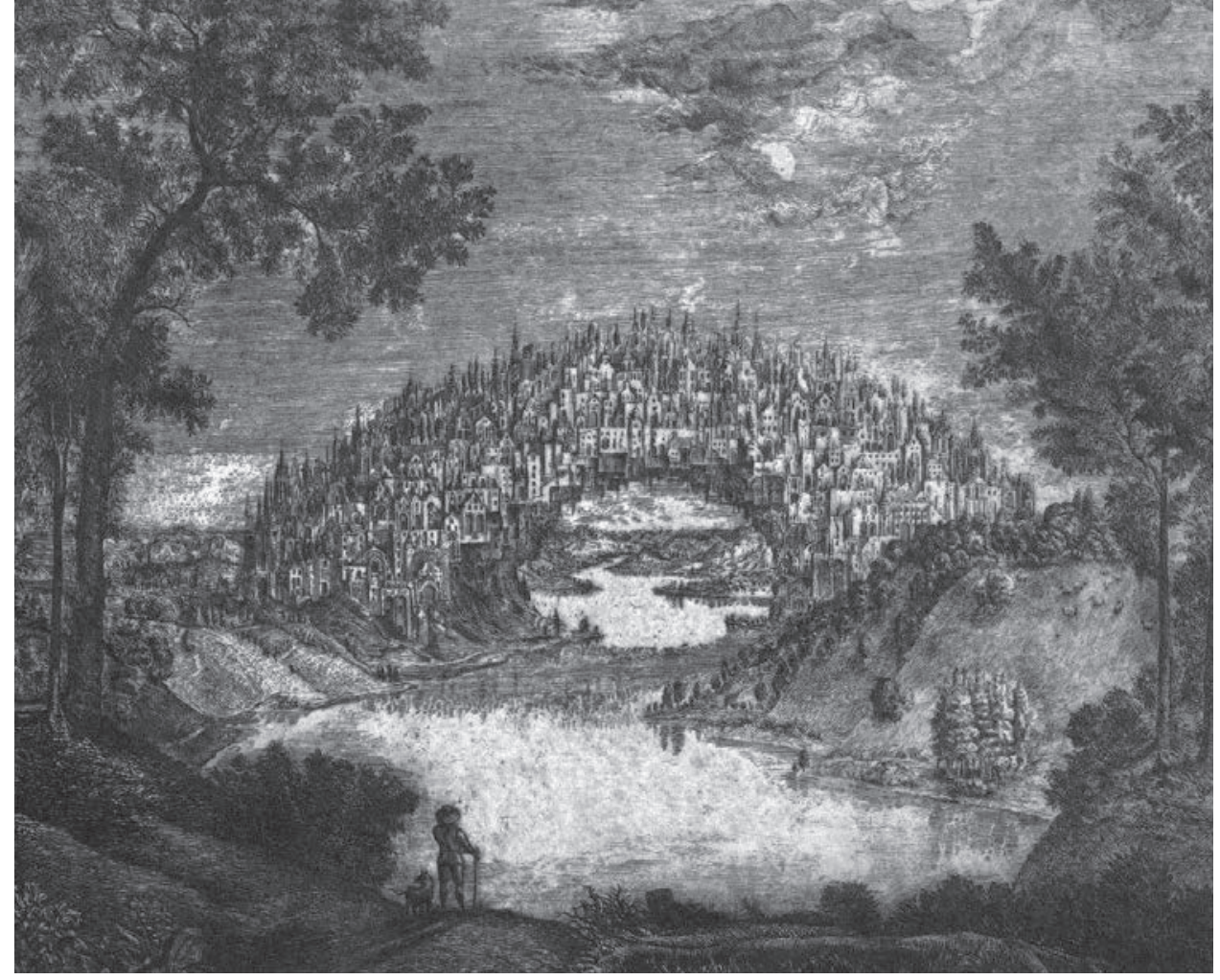

communist party resolved to abandon "excesses in design and construction" and to outlaw officially "nearly everything which had motivated architecture in the preceding twenty years: historicism, orientation to Classicism, richness of material and abundance of detail" (1994: 123). This impacted on the localized distribution of the sensible, changing what could be appropriately seen, spoken of, or propagated as architecture. By abolishing the production (the act of making visible) of a particular architectural approach, and by banning pedagogy associated with this aesthetic, the connection between the power of the state and its symbolic or literal depiction is manifest (Cooke, 1988). As Lois Nesbitt notes, from that point in time the communist party in Russia considered "aesthetic discourse of any kind ... unnecessary and immoral" (2003: n.p.). It is against this political backdrop that Brodsky and Utkin's architecture is viewed and interpreted in conventional architectural histories.

Brodsky and Utkin commenced their studies together at the Moscow Institute of Architecture in the mid 1970s. With few exceptions, they were taught by staff who had little choice but to support the architectural ideals of the state. After graduation, Brodsky and Utkin found that architectural practice was even more circumscribed, and there were few legitimate outlets for their creative energies. It was amidst this stifling professional atmosphere that they began to compete, illegally, in international ideas competitions and, in 1982, won the Japan Architect journal's "Central Glass Company" competition. Brodsky and Utkin's award winning entry, Crystal Palace, presents a towering glass structure sited at the edge of an unnamed town. From a distance, the structure is reminiscent of a grand expansion of Joseph Paxton's prototypical modern structure of the same name. Yet, to reach the seemingly magical Palace, travellers must venture into the decrepit margins of the city. Once they have crossed the urban wastelands, they soon discover that, instead of being a large enclosure filled with a cornucopia of delights, the structure is illusory. The Palace, which is constructed from a series of vertical "glass plates, stuck into the huge box of sand", is a mirage (Brodsky and Utkin, 1982: n.p.). It promises the viewer a wondrous destination, which "proves on closer inspection to be an illusion built on a municipal rubbish heap, and the flowers growing out of the urban litter turn out to be the blooms of dashed hopes" (Rappaport, 1994: 138). Like the majority of Brodsky and Utkin's works, Crystal Palace is presented on a single page and is rendered in dense black lines against the sepia surface of the paper. 


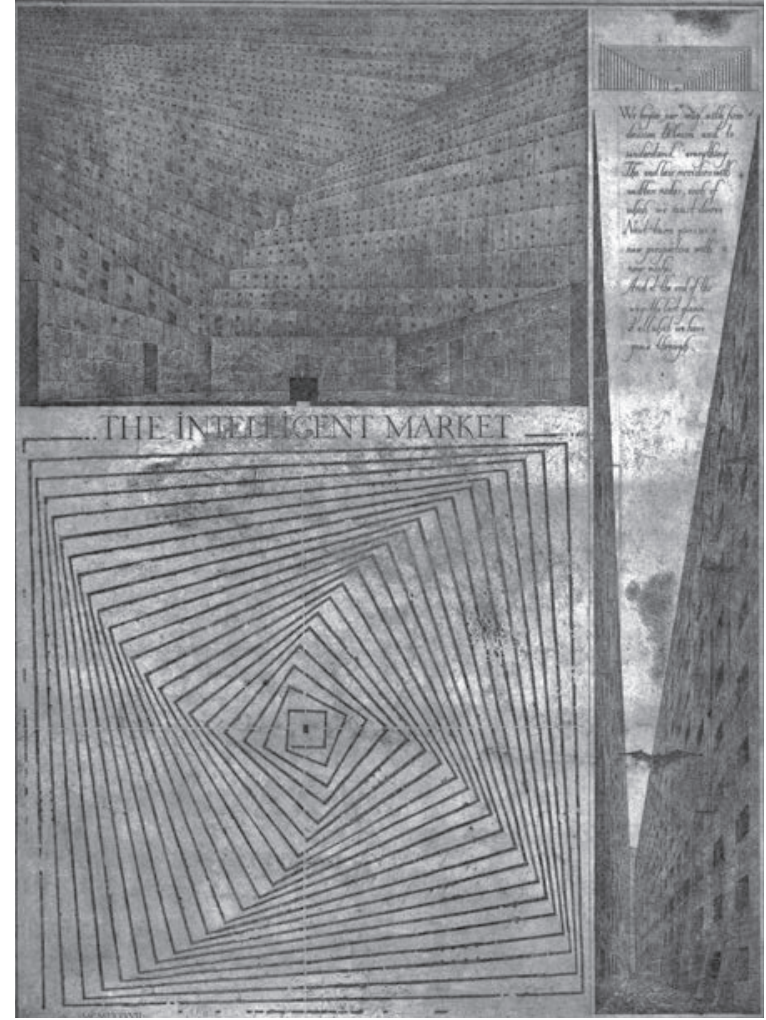

Brodsky \& Utkin, Town Bridge, 1984/90 (Plate produced / Plate printed) from Projects portfolio, 1981-90, 35 etchings, ed. of 30, $43 \times 313 / 4$ inches (F). Courtesy Ronald Feldman Fine Arts, New York. Photo by D. James Dee. [Originally drawn and published in 1984]

In 1984, Brodsky and Utkin completed a project, for an architectural competition, entitled Town Bridge, which featured a colossal arched bridge spanning a meandering river in a bucolic landscape: a place reminiscent of Gustave Doré's early etchings for Dante's Divine Comedy. The bridge is structured like a hypertrophic Ponte Vecchio: hundreds of townhouses, towers and steeples line the bridge creating a singular city. In the arcadian foreground, a traveller surveys the grandeur of the bridge. A later project, Hill with a Hole (1987a), offers a variation on this theme. Once again, it is sited in the mythical "landscape of old painters". However, this time, the inhabited bridge is more explicitly explained; it "doesn't enclose the landscape behind [it], being a kind of frame for it" but connects the "[p]ast and the [f]uture" (1987a: n.p.). Such projects are typical of Brodsky and Utkin and the Paper Architects' "dark etchings" (Rappaport, 1994: 135) in general. A hint of ennui tinges many of these works, as does a strong sense of irony. Thus, what is it in such works that allows them to be positioned as clearly political?

Constantin Boym (1992: 36) suggests that the Crystal Palace project is a criticism of post-war Moscow master planning; yet, there is little evidence in the drawing to identify the city as Moscow, or even modernist. It would be equally possible to read the Crystal Palace as a criticism of the vacuous nature of Western consumer society. The Town Bridge and Hill with a Hole projects certainly exemplify a desire for the rich urban fabric of historic cities. If there are conventional political intentions at all, they are present only through their absence. The projects evoke urban settings far removed from the everyday reality of the socialist state. The same equivocal dimension prevails in Columbarium Architecture, which calls for the construction of a "Museum for Disappearing Buildings" as a storage vault for discarded architecture. The drawings describe a funereal chapel, where miniatures of "[e]ach disappearing building, even the most unprepossessing" are exhibited (Brodsky and Utkin 1984: n.p.). This project seems to call for a memorial for all buildings, and their associated architectural styles, that had been destroyed by Communism. However, it also infers that there is an equal need to protect the neoclassical buildings of the Stalinist state. This is further dramatised in the project description, which proposes that capitalism may be the primary cause of the destruction of historic buildings. In none of these projects, all typical of their oeuvre, is there clear evidence of an assault on the police order. Brodsky and Utkin's architecture may not conform to the state's aesthetic values, but that does not necessarily make it an architecture of rebellion. 


\section{Retracing the Voyage}

The manner in which Brodsky and Utkin's architecture first became visible, or sensible, undoubtedly shaped its initial historical framing. Accounts of Brodsky and Utkin's careers typically stress that, in the early 1980s, it was still "illegal" for Soviet architects to seek international forums for their work (Boym, 1992: 36; Cruickshank, 1996: 1444). Thus, participation in the event, which rendered their work sensible, was, by definition, a form of opposition to the state. Also, Brodsky and Utkin's architectural aesthetic did not conform to the modernist approach authorised by the state and supported by the architectural profession. As Rappaport argues, the Paper Architects' initial crime was that, in their aesthetic approach, "they allowed themselves to do whatever they liked" (1994: 129-30). This led historians to read Brodsky and Utkin's architecture as a rejection of the police order, and therefore as a sign of opposition. However, in 1982, the Soviet state was already signalling its intention to embrace the administrative and economic reforms of perestroika and, in so doing, to join the post-political world. Perestroika and glasnost heralded new freedoms, and the first changes in the distribution of the sensible in Russia since the 1950s, certainly in terms of architecture. Thus, Brodsky and Utkin's architecture may have defied the law, but the police order had already begun to shift to accommodate a wider range of conditions and actions.

There is a substantial difference between a rejection of the law, which is - as a juridical dispute - one of many dimensions of and within the police order, and an attack on a political system. Juridical disputes, as instances of dissent, do not challenge the distribution of the sensible. In contrast, political disputes challenge the distribution of the sensible, resulting in dissensus. Dissensus "creates a fissure" in the "established framework" - it challenges the foundations of police order by questioning the partitioning of the sensible (Žižek, 2004: 85).

Politics may have a particular aesthetic, and the arts a political agenda, "[b]ut there is no formula for an appropriate correlation: it is the state of politics that decides" (Rancière, 2004b: 62). Les arts plastiques in themselves cannot constitute an attack on a political system, and there "are no criteria" for the work of art, or the aesthetic impulse, to be a subversive action. Instead, "[t]here are formulas ... whose meaning is often in fact decided upon by a state of conflict that is exterior to them" (2004b: 61). Thus, for Rancière, it is the role of the political system, or of opponents to the system, to frame an aesthetic work as constituting dissensus in relation to the police order.

These distinctions suggest that the relationship between the early architecture of Brodsky and Utkin and the Soviet state was one of dissent. How, then, did the canonical reading of Brodsky and Utkin's architecture as dissensus arise?

Ironically, it was the Soviet state that initially placed Brodsky and Utkin's work into a political framework. The state sought to capitalise on a rich underground practice of architecture in Moscow that was beating Western designs in international competitions. In 1984, the official Soviet Union of architects decided "that international recognition [for Paper Architecture] was advantageous to the State" (quoted in Boym, 1992: 21). It sponsored a modest exhibition of the Paper Architects' works in the offices of Younost in Moscow, where the state tacitly pardoned minor instances of dissent and presented the works as the products of 
Soviet ingenuity. As a result of the visibility provided by the state, more exhibitions soon followed in Europe and the United Kingdom and, in 1988, the Deutsches Architektur Museum staged a major exhibition that later toured North America. Thus, it was not until four years after the initial exhibition of Paper Architecture that historians began to frame the work in opposition to the Soviet state.

Heinrich Klotz records in the Architektur Museum's catalogue that, when he was initially confronted with the work of the Russian Paper Architects, he supposed that the projects had grown from the era of glasnost and perestroika. Yet, when he questioned the architects about their designs, they claimed that their ideas had formed throughout the Breshnev era. It "was under Breshnev's rule that all those rigid, large buildings that have disfigured Moscow's image were erected" (1989: 7). This led Klotz to propose that it was their brutal, totalitarian environment that lead these architects to "rebel against the petrification and to mobilize counterforces on paper. Their 'paper architecture' [is] a protest against a corrupted state architecture of former years" (1989: 7). Klotz's sentiments are echoed in Belov's assertion that these works "are not yet the fruits of perestroika - these will be harvested in the future. Rather, they are all the 'children of the stagnation', who have grown up in spite of it" (1988: 6). Rappaport argues that the work is a reaction against socialist attempts to create a utopian cityscape. The nature of totalitarian architecture, he states, "lies not only in gigantism or in the cult of power but also in a normative monotony which evolves in the course of a systematic realisation of utopias" (1989: 12). In 1990, eight years after the work first became visible, Nesbitt effectively cemented the canonical interpretation of Brodsky and Utkin's architecture as a "response to a bleak professional scene" in which only state authorized work could be constructed. For this reason, she concludes that Brodsky and Utkin's work “constitutes a graphic form of architectural criticism ... an escape into the realm of the imagination that ended as a visual commentary on what was wrong with social and physical reality and how its ills might be remedied" (2003: n.p.). ${ }^{6}$

In this canonical framing of Brodsky and Utkin's work, the relationship between it and the dominant police order gradually shifts from one of dissent to one of dissensus. Their position develops from a personal rejection of the power of the state, to a more visible criticism of the distribution of the sensible in Russia during the previous fifty years. While this seems a plausible interpretation, reality may be more complicated: the canonical reading falsely assumes that the ideological values of the Soviet state did not alter substantially throughout the 1980s. It also largely ignores the increased visibility of Brodsky and Utkin's architecture, which was promoted by state exhibitions in 1984 and 1987, as well as the later financial support which allowed them to show their work to the world. This leads to the supposition that the canonical interpretation may be reliant on the manufacturing of dissensus.

To account for the visibility, or sensibility, of Brodsky and Utkin's architecture in the late 1980s - in terms of the distribution of the sensible in Russia from the 1950s to the 1970s - Western European and North American writers constructed a peculiar history of their work. Lacking reference to a dominant political and ideological context, historians chose the one that was most closely aligned with the formative years of the architects. However, in terms of the distribution of the sensible, this misalignment may say more about the West's desire to promulgate
6. It is important to note that the framing of Brodsky and Utkin's position in architectural history is complicated by two things: first, their close involvement with the Paper Architecture movement and, second, the relative paucity of their own writings. Brodsky and Utkin speak through their architecture, not through manifestos or polemics. However, there is a clear tendency to ascribe to Brodsky and Utkin, as prominent members of the Paper Architecture movement, views and opinions expressed by other members. This paper suffers from the same two flaws. Particularly significant here is the reframing of their architecture via its framing by secondary sources. This, however, is precisely why a Rancièrian analysis of the distribution of the sensible holds more promise than conventional historical methods. 
a heroic vision of the architect rejecting the will of the Soviet state, than it does about life in Russia during a time of great political change.

Arguably, Brodsky and Utkin's architecture did not disturb the distribution of the sensible in either the East or the West. Rather, it was framed by both sides in terms of their own opposed political positions: the former as an example of Russian ingenuity, the latter as a reaction to state oppression. These framings are examples of what Rancière calls the "politicization" of a work (2004b). Without a clear ideological context, the production of history relies on localized framings, which often reveal more about their own methodological biases than they do about the architecture they are considering. Seen in this way, the canonical interpretation of Brodsky and Utkin's work is problematic, precisely because it lacks a critical awareness of its own construction.

\section{Running aground}

The Ship of Fools project is the closest Brodsky and Utkin come, in any of their works, to a personal commentary. While many of their etchings offer a similar level of sublime beauty, only this project provides clues to the social and cultural reality of their endeavours. Two short extracts from poems, almost hidden in the etching, assist in this regard.

The first stanza is written on the vessel itself; the second half-concealed in the smoke above the city. The first reads:

Come Here, brothers, idler men!

We are sailing on a ship

To Land of Fool's around the world,

But here-hay! We run ashore! [sic.]

(Brant, S. "Ship of Fools" quoted in Nesbitt, 2003: n.p.).

Remember that, according to Rancière, the purpose of philosophy is to drag the aimless vessels of politics "to dry land" (1995: 1), to force wayward apolitical mariners to confront ideology once more. The terra firma on which the Ship of Fools has run aground is a bleak, overcrowded, industrial city, "magnificent in [its] gloom and density" (Boym, 1992: 38).

The second fragment of poetry is, fittingly, from a poem by Pushkin entitled "A feast during the plague". It describes a gathering raising their glasses to toast the epidemic: a final act of bravado. With these additional fragments, the earlier interpretation of the work is expanded. The ship is not sailing through an urban ocean, as Rappaport obliquely suggests, but it has finally left behind its aquatic meanderings to confront the real world. This is not an heroic image; it acknowledges the challenge ahead at the same time as it bids a mocking farewell to the past. There are no political apparitions in the etching: the ship has not found a utopian isle, it has run headlong into the reality of the post-political world.

The year 1988, when the Ship of Fools project was completed, effectively marks the end of the Paper Architecture movement. At that time the work of the previous decade was collected, widely exhibited and indelibly recorded in the history 
books. While the members of the movement, including Brodsky and Utkin, separately went on to produce more substantial architectural designs, the framing of their earlier works has remained largely unchanged since then. The Ship of Fools presciently marks this shift: it is the last work of a group who knew that they were no longer so isolated or constrained. Their work had reached an international stage, and the dissolution of the Soviet Union was barely two years away. Unfortunately, within a few more short years, the interest in these great works of paper architecture would also wane, and the histories that had already been written would lie undisturbed.

\section{References}

Badiou, A. (2004). Infinite Thought: Truth and the Return of Philosophy (O. Feltham \& J. Clemens, Trans.). New York: Continuum.

Badiou, A. (2005). Metapolitics (J. Barker, Trans.). New York: Verso.

Belov, M. (1988). Children of the Stagnation. In Nostalgia of Culture: Contemporary Soviet Visionary Architecture (pp. 6-7). London: Architectural Association.

Bown, M. C. \& Taylor, B. (Eds.). (1993). Art of the Soviets: painting, sculpture, and architecture in a one-party state, 1917-1992. New York: St. Martin's Press.

Boym, C. (1992). New Russian Architecture. New York: Rizzoli.

Brodsky, A. \& Utkin, I. (1982). “Crystal Palace”. Reprinted in L. E. Nesbitt (2003). Brodsky and Utkin: The Complete Works. (Plate 6, n.p.). New York: Princeton Architectural Press.

Brodsky, A. \& Utkin, I. (1984). “Columbarium Architecture (Museum for Disappearing Buildings)". Reprinted in L. E. Nesbitt (2003). Brodsky and Utkin: The Complete Works. (Plate 2 unpag.). New York: Princeton Architectural Press.

Brodsky, A. \& Utkin, I. (1987). “Hill with a Hole”. Reprinted in L. E. Nesbitt (2003). Brodsky and Utkin: The Complete Works. (Plate 16, n.p.). New York: Princeton Architectural Press.

Brodsky, A. \& Utkin, I. (1988). “Ship of Fools". Reprinted in L. E. Nesbitt (2003). Brodsky and Utkin: The Complete Works. (Plate 20, n.p.). New York: Princeton Architectural Press.

Brumfield, W. C. (1991). The origins of modernism in Russian architecture. Berkeley: University of California Press.

Cooke, C. (1988). A Picnic by the Roadside or Work in Hand for the Future? In Nostalgia of Culture: Contemporary Soviet Visionary Architecture (pp. 11-26). London: Architectural Association.

Cruickshank, D. (Ed.). (1996). Sir Banister Fletcher's a history of architecture. 20th ed. Oxford: The Architectural Press.

Dovey, K. (1990). Framing Places: Mediating Power in Built Form. London: Routledge.

Findley, L. (2005). Building Change: Architecture, Politics and Cultural Agency. London: Routledge.

Frampton, K. (1992). Modern Architecture: A Critical History. 3rd Edition. London: Thames and Hudson.

Khan-Magomedov, S. O. (1987). Pioneers of Soviet architecture: the search for new solutions in the 1920s and 1930s (A. Lieven, Trans.). London: Thames and Hudson.

Klotz, H. (Ed.). (1989). Paper Architecture: New Projects from the Soviet Union. New York: Rizzoli.

Kopp, A. (1970). Town and Revolution: Soviet Architecture and City Planning 1917-1935. London: Thames and Hudson.

Kopp, A. (1985). Constructivist Architecture in the USSR. London: Academy Editions. 
Millon, H. A. \& Nochlin, L. (Eds.). (1978). Art and Architecture in the Service of Politics. Cambridge (Mass): MIT Press.

Nesbitt, L.E. (2003). Brodsky and Utkin:The Complete Works. New York: Princeton Architectural Press. [first ed. 1990]

Papadakis, A. C. (Ed.). (1991). The Avant-garde : Russian architecture in the twenties. New York : St. Martin's Press

Rancière, J. (1991). The Ignorant Schoolmaster: Five Lessons in Intellectual Emancipation (K Ross, Trans.). Stanford (Ca.): Stanford University Press.

Rancière, J. (1994). The Names of History: On the Poetics of Knowledge (H. Melehy Trans.). University of Minnesota Press.

Rancière, J. (1995). On the Shores of Politics (L. Heron, Trans.). New York: Verso.

Rancière, J. (2000). Literature, Politics, Aesthetics: Approaches to Democratic Disagreement. Interview with Solange Guénoun and James H. Kavanagh. SubStance, 29(2), 3-24.

Rancière, J. (2004a). The Philosopher and His Poor (J. Drury, Trans.). Durham: Duke University Press.

Rancière, J. (2004b). The Politics of Aesthetics (G. Rockhill, Trans.). London: Continuum.

Rancière, J. (2004c). The Flesh of Words: The Politics of Writing (C. Mandell, Trans.). Stanford (Ca): Stanford University Press.

Rancière, J. (2007a). Hatred of Democracy. New York: Verso.

Rancière, J. (2007b). The Future of the Image (G. Elliott, Trans.). New York: Verso.

Rappaport, A. (1989). Language and Architecture of Post-Totalitarianism. In H. Klotz, (Ed.). Paper Architecture: New Projects from the Soviet Union (pp. 11-17). New York: Rizzoli.

Rappaport, A. (1994). Paper Architecture A Postscript. In A. Yurasovsky \& S. Ovenden (Eds.). Post Soviet Art and Architecture (pp. 128-143). London: Academy Editions.

Schumacher, T. L. (1993). The Danteum: Architecture, Poetics, and Politics under Italian Fascism. New York: Princeton Architectural Press.

Tarkhanov, A. (1994). Post-Modernism on a Scale of 1:666: The Phenomenon of 'Paper Architecture' in the USSR. In A. Yurasovsky \& S. Ovenden (Eds.). Post Soviet Art and Architecture (pp. 122-127). London: Academy Editions.

White, H. (1994). Foreword. In J. Rancière, The Names of History: On the Poetics of Knowledge (pp. vii - xx). Minneapolis: University of Minnesota Press.

Žižek, S. (2004). Glossary of Technical Terms. In J. Rancière, The Politics of Aesthetics (G. Rockhill, Trans.) (pp. 80-93). London: Continuum. 